\title{
Performance Evaluation of the Extension Worker and the Development Strategy of Organic Agriculture Extension in Batu City
}

\author{
Hendro Prasetyo* and Lilis Hariani \\ Department of Socioeonomics, Faculty of Agriculture, Universitas Brawijaya Malang
}

(Received April 12, 2018; accepted October 15, 2018; published December 8, 2018)

\begin{abstract}
The area of Batu City generally performs high agricultural productivity. Batu is known as a producer of food and horticultural commodities that meet the needs of other regions. However, an excessive use of chemical pesticides and fertilizers in agricultural land has resulted in reducing land quality and productivity. Regarding such issues, the municipal government of Batu city encourages the implementation of organic farming. The role of extension workers is expected to be able to provide implementation up to the level of farmer cultivation management. The objectives of this study include (1) evaluating the performance of agricultural extension services, (2) identifying the internal and external environment of the organic agriculture extension program, (3) analyzing the strategy for developing an organic agriculture extension program. The study was conducted in the District of Junrejo Bumiaji Batu. Farmers and key persons were interviewed to obtain perceptual variables on the performance of extension workers, and strategies to increase the role of extension workers. The results of this study indicate that the performance of agricultural extension in seven indicators is sufficient. Only one indicator that has unsatisfactory performance is the media used in education counseling. Strategies for increasing the role of extension workers include: (1) improving information about organic agriculture by improving extension methods, (2) increasing the ability of farmer groups by working with stakeholders, (3) improving more effective and efficient extension methods, (4) improving the number of extension agents to optimize services for farmers, and (5) improving the quality of extension workers.
\end{abstract}

Keywords: evaluation program, organic farming, Bumiaji, extension

JEL Classification: Q16, Q58, Q56

\section{INTRODUCTION}

Regional economic development requires an integrated study of environmental aspects and social capacity. This concept can use a comparative advantage and agglomeration approach, associated with the function of economic integration with other regions. This approach can lead to sustainable development (Parmawati, Soemarno, Nugroho, \& Setiawan, 2012).

Batu City, East Java province, is located in a highland area starting from $600 \mathrm{~m}$ to $2,300 \mathrm{~m}$ above sea level. The development of the agricultural sector still dominates the regional

\footnotetext{
* Corresponding author email: hendroprasetyoub@gmail.com, ISSN 2615-6075 online; ISSN 2615-6946 print @UWG Press, 2018

OJS http://publishing-widyagama.ac.id/ejournalv2/index.php/jsed/
}

economy, with the characteristics of the comparative advantage of sub-tropical commodities. Soil fertility conditions are suitable for the cultivation of vegetables and fruits. The cool and comfortable climate makes Batu as mainstay of a tourist destination. This needs attention in the management of land and regional resources to produce sustainable development benefits.

The development of organic agriculture is a real manifestation of the Batu City government efforts to implement sustainable agricultural development (Fadlina, Supriyono, \& Soeaidy, 2013). One area in Batu city that implements an organic farming program is Bumiaji district. Bumiaji district is one of the areas in Batu City which has an altitude of more than $1300 \mathrm{~m}$ above sea level. This area is adjacent to a forest park conservation area, known as the Sumberbrantas area. The majority of Sumberbrantas people have planted vegetables 
such as carrots, potatoes, blumkool, shouldard greens, shallots. Some others plant apples, but the implementation is still conventional. It means that the use of chemical fertilizers and inorganic pesticides are excessive, so that it is enable to reduce soil fertility and soil productivity.

The Agriculture Office of Batu City has established and implemented an organic farming program since 2010 as the efforts to restore the level of soil fertility. One of which was in Bumiaji district. The "Go Organic of Batu City" program aims to improve soil fertility, biological quality and health of the soil, produce healthy and qualified agricultural products, increase farmer incomes, encourage the advancement of organic agriculture in Batu city, and support sustainable agriculture (Sumbayak, 2013).

For the success of the Organic Agriculture Program, Agricultural Extension Resources are needed to provide guidance and counseling to the community through socialization, technical assistance, production inputs, harvesting, and marketing.

The problem often faced by farmers in rural areas is the low availability of new information needed (Fangohoi, Sugiyanto, Sukesi, \& Cahyono, 2018). This is increasingly felt when new programs, procedures and technology are applied. The new program should be prepared in such a way that contains a full explanation and is received uniformly by all parties. It may be that a lot of information is available from various sources, but the accuracy should be identified. This information can be useful as the first step to understand the problem which is then followed up with a solution.

The provision of this information needs to be managed properly. Extension workers, farmers and stakeholders can learn to use this information to be more useful. The availability of information can also create technological innovations in agriculture and support services.

The "Go Organic of Batu City" program also needs to be well prepared, through the role of extension workers. The performance of extension workers should be able to oversee the program and provide guidance to groups of program participants. Extension workers in the field foster two farmer groups, namely the conventional majority group, and minority farmer groups who follow the pilot of the organic farming program. The area of the pilot program is 10 ha per village.

In order to run the program well, the right strategy is needed in accordance with environmental conditions both internally and externally to maximize the extension program (Aminah, Sumardjo, Lubis, \& Susanto, 2015), so the extension program can achieve the expected goals of the Batu city government.

The process of implementing agricultural extension can carry well and correctly if it is supported by professional extension workers, reliable extension agencies, continually flowing counseling materials, the correct system of extension education and appropriate extension methods (Sairi, 2015)

In short, the purpose of this study is to assess the performance of agricultural extension services and develop strategies for increasing the role of extension agents to support organic farming programs in Batu city.

\section{RESEARCH METHOD}

Survey research was carried out in the city of Batu. Research respondents included organic farmers and key persons. A total of 40 farmers were selected randomly, from the villages of Giripurno, Tulungrejo and Sumberbrantas, Bumiaji district. Farmers were interviewed to get their perception regarding the performance of extension workers in carrying out their duties.

Three key persons were interviewed to fill out the questionnaire, to get their responses in formulating a strategy to increase the role of extension agents.

Research analysis methods include description analysis and strategy formulation or SWOT

\section{Descriptive Analysis}

Descriptive analysis is used to determine the performance of extension with two assessments, which are good and not good. The assessment criteria are explained based on each indicator value compared to the average value. Indicator variables of farmers' perception of extension's performance include (i) the development of farmer and gapoktan groups, (ii) the extension work programs, (iii) the 
extension approaches, (iv) the extension media, (v) the extension methods, (vi) facilities and infrastructure, and (vi) coordination between extension agents. The results of the extension's performance form the basis for the preparation of internal factors in the SWOT analysis.

\section{SWOT Analysis}

SWOT analysis is the identification of various factors systematically to formulate an organization or institutional strategy. This analysis is based on the subject of the internal environment that can maximize the strengths and opportunities; and external environment which can minimize weaknesses and threats (Helms \& Nixon, 2010).

Internal factors in the strength variable include government support, development of farmer groups and a combination of farmer groups, quality of extension workers, extension work programs and approach methods. Meanwhile, the weakness variables are counseling media, counseling methods, facilities and infrastructure, coordination among extension agents, and the limited number of extension agents.

The external factors on opportunity variables include cooperation with stakeholders, the availability of organic farming inputs, periodic monitoring, high prices of organic products, and market opportunities. Meanwhile, the threat variable includes the level of participation, the lack of information from farmers on organic farming, the lack of services optimization, the narrowness of land ownership, and the occurrence of land conversion.

The variables were then given the value of the results from the respondent survey, and were arranged into the IFAS (Internal Strategic Factors Summary) and EFAS (External Strategic Factors Summary) tables (Rangkuti, 2006).

The calculation of scores was obtained from the results between weight and rating. The IFAS table was used to assess weight and rating on the assessment of internal factors aimed at the strengths and weaknesses faced by the extension agent, so that it can deal with internal weaknesses and take a position to correct them. EFAS table was used to assess the weight and rating on the assessment of the high and low values of opportunities found in the farmer's environment as well as threats arising from an external environment.

The identification of internal and external factors was expressed by calculating the total score obtained. Then the difference between internal and external factors was arranged as follows:

a. Internal factor $=$ (strength - weakness $)=$ horizontal y axis

b. External factors $=$ (opportunities - threats $)=$ vertical $x$ axis

The next procedure was to compile a SWOT diagram. Diagram is useful for knowing the position of an organization. The SWOT diagram is divided into four parts, namely:

a. Quadrant I is to support an aggressive strategy or the SO strategy (strenght opportunities)

b. Quadrant II is to support a strategy that is oriented to the change of strategy WO (weaknesses - opportunities)

c. Quadrant III is to support a defensive strategy or WT (weaknesses - threats) strategy

d. Quadrant IV is to support the diversification strategy or the ST (strength - threats) strategy

Based on the position of the quadrant, the extension development strategy can be determined by using the IFAS/EFAS Table. Merging among variables of strengths, weaknesses, opportunities, and threats was carried out based on the diagram.

\section{RESULT AND DISCUSSION}

\section{The Extension Performance Evaluation}

The results of the analysis to measure farmers' perception of the extension agents performance are presented in Table 1, covered in seven variables. In general, those variables adjust the performance indicators as stated in the Regulation of the Minister of Agriculture No. 91/Permentan/OT.140/9/2013 concerning guidelines for evaluating the performance of agricultural extension officers.

Farmers' perception of the development variables of farmer groups and farmer groups played by extension agents showed positive things. As many as $73 \%$ of respondents said that the 
performance of the extension agent was good, and 27 others said it was bad. Farmer groups and joint farmer groups already have the ability in organizing, accounting and building organizational structures properly.

Table 1. Farmers' Perception of the Performance of Extension Workers

\begin{tabular}{clcc}
\hline No & Variable Perception of farmers & Good & $\begin{array}{c}\text { Not } \\
\text { good }\end{array}$ \\
\hline 1 & $\begin{array}{l}\text { Development of farmer groups } \\
\text { and joint farmer groups. }\end{array}$ & 73 & 27 \\
2 & Extension work program & 67 & 33 \\
3 & Approach method & 52 & 48 \\
4 & Counseling media & 62 & 38 \\
5 & Counseling method & 72 & 28 \\
6 & Facilities and infrastructure & 69 & 31 \\
7 & Coordination between extension & 66 & 34 \\
& & \\
\hline
\end{tabular}

Farmers' perception of the extension work program variable showed positive things, where $67 \%$ of respondents stated that the extension's performance was good, and 33 others stated badly. Farmer groups and farmer groups combined Farmer groups in Bumiaji district consider that the agricultural extension work program is considered good because the work program created has been felt to be directed towards farmers or has helped farmers in doing farming.

The farmer's perception of the method variable approach carried out by the extension agent shows a more or less neutral. $52 \%$ of respondents said that the performance of the extension agent was good, and 48 others stated it was bad. The farmer group considers that the extension approach method is quite efficient or appropriate for the farmer groups so that the they are able to receive the program that will be provided by the government well.

The performance of the extension approach method is not better than the previous two variables. Approach methods need to be improved to make them more acceptable to farmers, and agricultural programs can work better.

Farmers' perception of the media variables of counseling conducted by extension agents shows a positive thing. As many as $62 \%$ of respondents said that the performance of the extension agent was good, and 38 others stated it was bad. The farmer groups consider that the available extension media is quite good according to the their needs.
However, the observation shows that the media used to carry out the extension process is considered to be less varied so that farmers feel bored with the extension media used (Fangohoi et al., 2018).

Farmers' perception of the extension method variables carried out by extension agents shows very good. A total of $72 \%$ of respondents said that the performance of the extension agent was good, and 28 others stated bad. The farmer group considers that the extension method used such as a face-to-face and lecture method are considered good enough to convey information to farmer groups in Bumiaji district.

Farmers' perception of the facilities and infrastructure variables of counseling conducted by extension agents shows a positive thing. As many as $69 \%$ of respondents said that the performance of the instructor was good, and 31 others said they were bad. Farmer groups have a positive perception and feel the facilitation of the facilities and infrastructure are usefull.

Farmers' perception of the coordination variable of extension activities shows a positive thing, where $66 \%$ of respondents stated that the performance of extension agents was good, and 34 others stated bad. The farmer considers that the coordination between extension agents conducted in Bumiaj district is considered quite good. The coordination is carried out at once a month, as performance indicators according to Minister of Agriculture Regulation Number 91/Permentan/OT.140/9/2013 concerning guidelines for evaluating agricultural extension.

\section{The Strategy for Enhancing Extension Performance}

1. The Analysis of internal and external environment

The results of internal and external environmental analysis are presented in Tables 2 and 3. Table 2 shows the results of the calculation of the scores of each internal variable on strength (ranging from 0.33 to 0.47 ) or weaknesses (ranging from 0.38 to 0.42 ). The number of strength and weakness factor scores is 2.03 and 1.98 , respectively. This shows that strength displays a position more dominant than weakness, resulting in a score difference of 0.05 . 
Table 2. The Calculation of IFA score

\begin{tabular}{|c|c|c|c|}
\hline Variable & Bobot & Rating & Score \\
\hline \multicolumn{4}{|l|}{ Power } \\
\hline Government Support & 0.091 & 3.6 & 0.33 \\
\hline $\begin{array}{l}\text { Development of farmer groups } \\
\text { and joint farmer groups }\end{array}$ & 0.109 & 4.3 & 0.47 \\
\hline Quality of HR extension agents & 0.102 & 4.1 & 0.41 \\
\hline Extension work program & 0.097 & 3.9 & 0.37 \\
\hline Approach Method & 0.105 & 4.2 & 0.44 \\
\hline Total Score & & & 2.03 \\
\hline \multicolumn{4}{|l|}{ Weakness } \\
\hline Extension Media & 0.103 & 4.1 & 0.42 \\
\hline Extension Method & 0.099 & 3.9 & 0.39 \\
\hline Facilities and infrastructure & 0.098 & 3.9 & 0.38 \\
\hline $\begin{array}{l}\text { Coordination between extension } \\
\text { agents }\end{array}$ & 0.099 & 4.0 & 0.39 \\
\hline $\begin{array}{l}\text { Limited number of extension } \\
\text { agents }\end{array}$ & 0.099 & 4.0 & 0.39 \\
\hline Total Score & & & 1.98 \\
\hline
\end{tabular}

Table 3 shows the results of calculating the scores of each internal variable on opportunities (ranging from 0.29 to 0.45 ) or threats (ranging from 0.30 to 0.45 ). The number of opportunity and threat factor scores is 1.70 and 2.01, respectively. This shows that the threat performs a greater position than the opportunity, resulting in a score difference of -0.30 .

The difference in scores from IFAS and EFAS tables is then used to compile the $X$ and $Y$ axes on the SWOT diagram, presented in Figure 1.

Table 3. The Calculation of EFAS scores

\begin{tabular}{lccc}
\hline Variable & Weight & Rating & Score \\
\hline $\begin{array}{l}\text { Opportunity } \\
\text { Collaboration with stakeholders }\end{array}$ & 0.096 & 3.5 & 0.34 \\
$\begin{array}{l}\text { There is assistance from organic } \\
\text { farming inputs }\end{array}$ & 0.111 & 4.1 & 0.45 \\
$\begin{array}{l}\text { Periodic supervision } \\
\text { The high price of organic }\end{array}$ & 0.090 & 3.3 & 0.30 \\
products & 0.089 & 3.3 & 0.29 \\
$\begin{array}{l}\text { Market opportunity } \\
\text { Total Score }\end{array}$ & 0.093 & 3.4 & 0.32 \\
$\begin{array}{l}\text { Threat } \\
\text { Level of participation }\end{array}$ & 0.103 & 3.8 & 0.39 \\
$\begin{array}{l}\text { The lack of information from } \\
\text { Farmers on organic farming } \\
\text { Lack of service optimization }\end{array}$ & 0.111 & 4.1 & 0.45 \\
$\begin{array}{l}\text { Narrow land ownership } \\
\text { Occurrence of land conversion }\end{array}$ & 0.106 & 3.9 & 0.41 \\
Total Score & 0.111 & 3.3 & 0.30 \\
\hline $\begin{array}{l}\text { The number of respondents is } 40 \text { people } \\
\text { Difference in score: -0.30 }\end{array}$ & & & 0.45 \\
\end{tabular}

The diagram explains that the position of the SWOT coordinates is in quadrant IV. This means that extension programs or activities should use diversification strategies (ST strategy). Counseling should minimize existing weaknesses and threats as well. It should be to determine the diversification strategy of the strengths and maximize the available opportunities to be able to maintain the continuity of agricultural extension in Bumiaji District.

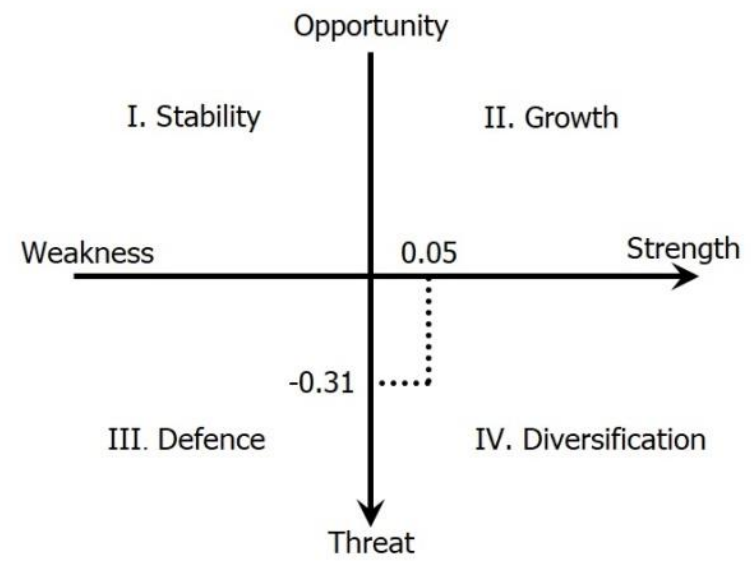

Figure 1. SWOT diagram

Another way to look at alternative or strategic priorities is to use the SWOT matrix by adding EFAS scores to IFAS. The total value of each factor is illustrated in the formulation of the SWOT matrix which can be seen in Table 4.

Table 4. Summing up of IFAS and EFAS scores

\begin{tabular}{lcc}
\hline EFAS/IFAS & Strenght $(\mathrm{S})$ & Weakness $(\mathrm{W})$ \\
\hline Opportunity (O) & SO & WO \\
& $=2.03+1.70$ & $=1.98+1.70$ \\
& $=3.73$ & $=3.68$ \\
Threat $(\mathrm{T})$ & ST & WT \\
& $=2.03+2.01$ & $=1.98+2.01$ \\
& $=4.04$ & $=3.98$ \\
\hline
\end{tabular}

Table 4 shows that the ST strategy value (4.04) shows the highest score, followed by WT (3.98), SO (3.73) and WO (3.68). The ST strategy from Table 4 is also in line with Figure 1. The sequence also provides an explanation of the priority strategies needed to improve the success of organic agriculture counseling.

\section{The Development strategy}

The development strategy for extension services was prepared on the basis of the SWOT matrix (Table 5). As explained previously, the priority of strategies can be drawn up, namely ST (4.04), WT (3.98), SO (3.73) and WO (3.68). 
The SWOT analysis method is recognized to be very commonly used by practitioners. The advantages of the SWOT method are because it is simple and easy to apply. However, caution is still needed and can not be separated from the concept of field theory being studied. The strategies compiled from the SWOT analysis should be examined, by relying on scientific field competencies, including being equipped with other analytical tools (Helms \& Nixon, 2010).

Table 5. The Extension of Performance Development Strategies Based on the SWOT Matrix

\begin{tabular}{|c|c|c|}
\hline $\begin{array}{lll}\text { IFA } & & \\
& & \\
& \text { EFf }\end{array}$ & $\begin{array}{l}\text { Strength (S) } \\
\text { 1. Government support } \\
\text { 2. Development of a joint farmer group } \\
\text { 3. Quality of HR extension agents } \\
\text { 4. Extension program work } \\
\text { 5. Approach method }\end{array}$ & $\begin{array}{l}\text { Weakness (W) } \\
\text { 1. Extension media } \\
\text { 2. Extension methods } \\
\text { 3. Facilities and infrastructure } \\
\text { 4. Coordination of extension agents } \\
\text { 5. Limited number of extension } \\
\text { agents }\end{array}$ \\
\hline $\begin{array}{l}\text { Opportunity }(\mathrm{O}) \\
\text { 1. Collaboration with stakeholders } \\
\text { 2. Assistance for organic farming inputs } \\
\text { 3. Periodic supervision } \\
\text { 4. The high price of organic products } \\
\text { 5. Market opportunities }\end{array}$ & $\begin{array}{l}\text { Strategy SO } \\
\text { (score 3.73) }\end{array}$ & $\begin{array}{l}\text { Strategy WO } \\
\text { (score } 3.68 \text { ) }\end{array}$ \\
\hline $\begin{array}{l}\text { Threat (T) } \\
\text { 1. Level of participation } \\
\text { 2. Information on organic farming } \\
\text { 3. Lack of service optimization } \\
\text { 4. Narrow land ownership } \\
\text { 5. Occurrence of land conversion }\end{array}$ & $\begin{array}{l}\text { Strategy ST } \\
\text { (score 4.04) }\end{array}$ & $\begin{array}{l}\text { Strategy WT } \\
\text { (score 3.98) }\end{array}$ \\
\hline
\end{tabular}

The combination strategy of Strength Opportunity (S-O). The strategy is intended to use power to take the advantage of opportunities.

a. Increasing the government support to socialize the price of organic products to support competitiveness

b. Increasing government support by opening market opportunities to improve the marketing supply chain system and support Batu's tourism

c. Improving the ability of farmer groups by collaborating with stakeholders to improve agribusiness and agro-industry based on the organic agriculture (Hapsari, Hakim, \& Soeaidy, 2014)

d. Increasing the price of organic products through the role of farmer groups to improve the quality of cultivation

e. Improving cooperative relations with stakeholders to improve the quality of $\mathrm{HR}$ extension agents (Fadlina et al., 2013)

f. Improving the work program of extension workers with regular supervision (Herlina, 2014) g. Collaborating with stakeholders to improve the extension approach method through diversification of agricultural products

h. Improving the extension approach method to build a good and efficient communication to develop farmer groups

The strategy for the integration of Weakness Opportunity (W-O). The strategy is aimed at minimizing weaknesses to take the advantage of opportunities.

a. Increasing collaboration with stakeholders to improve extension media

b. Reconditioning and improving extension facilities and infrastructure by collaborating with stakeholders (Fadlina et al., 2013)

c. Improving extension facilities and infrastructure to provide organic farming inputs

d. Improving supervision regularly by improving extension facilities and infrastructure to improve organic farming

e. Improving extension facilities and infrastructure to improve innovation and quality of organic cultivation to produce competitive prices for organic products 
f. Improving extension facilities and infrastructure to improve market opportunities for organic agriculture.

The combination Strategy of Strength - Threat $(\mathrm{S}-\mathrm{T})$. The strategy is intended to use force to overcome threats.

a. Increasing farmer participation in programs and government relations to realize agricultural diversification in Batu city

b. Improving the quality of HR extension agents to motivate increased farmer participation

c. Improving the extension approach method to increase the farmer participation

d. Increasing government support to improve the provision of information on organic farming to farmers

e. Improving the quality of extension agents to improve information and communication flows (Sairi, 2015) regarding organic farming to farmers

f. Increasing the government support to overcome the ownership of a small-size land so that the production continues to increase

g. Requesting government support to limit the conversion of agricultural land

h. Developing the competency of farmer groups as an effort to suppress the occurrence of land conversion

The strategy for fusion of Weakness - Threats $(\mathrm{W}-\mathrm{T})$. Strategies are aimed at minimizing weaknesses and avoiding threats.

a. Improving more effective and efficient counseling methods such as the use of the internet to increase farmer participation (Fangohoi et al., 2018)

b. Improving information about organic farming by improving extension methods

c. Improving optimization of services by improving the facilities and infrastructure of extension services

d. Improving coordination between extension agents in delivering information about organic farming

e. Increasing the intensity of coordination among extension agents to maximize extension services f. Doing Recruitement of new extension agents to maintain continuity of information on organic farming to farmers

g. Increasing the number of extension agents to optimize services for farmers

h. Increasing the development of joint farmer groups by increasing the number of extension agents so that the performance of extension agents is better.

\section{The Strategic Implications}

The strategic implication of this research is basically the S-T strategy. The strategy is intended to use force to overcome threats. In Figure 1, the strategy is directed at diversifying extension programs. The internal factors of the strength that need to be optimized are basically the extension agent and the farmer himself.

Agricultural extension activities are very important to provide assistance to farmers and their families. Farmers are expected to have the ability to help themselves to achieve their goals in improving the welfare of the farmers and their families (Sairi, 2015).

Furthermore, the role of the instructor should be optimized in various functions, namely as a communicator, educator, facilitator, mediator or motivator. That role puts extension workers as a solution to the problems of all things faced by farmers. They should be able to master the technical and social relations with various parties/other parties in the development of farming, including to empower farmers or small businesses (Hapsari et al., 2014).

Extension agents are required to serve better to farmers and are able to motivate the spirit of learning and innovating in farmer groups, participating in advancing groups. Extension agents are also always present to explain to farmers about land ownership, land conversion and an adverse asymmetric information. The role of extension agents becomes increasingly important when farmers are faced with farming cooperation with the private sector, or investors (Fadlina et al., 2013).

The position of farmer groups or farmers in Batu city basically has advanced. They are familiar with commercial farming compared to most 
farmers in other region. They have been contributing in advancing agro tourism in Batu. Nonetheless, its role should continue to grow as the progress and intensity of requests from outside the region.

The Batu Go Organic program should be directed at forming farmers who independently apply the organic farming. They still need to be accompanied as long as they need or encounter difficulties. The weakness of farmers is usually when dealing with farming stakeholders, they do require energy and social competence which is quite complex. This multi-functional activity requires a helping hand from the government including extension agents to coordinate, integrate or provide new information.

The Go Organic program is multi-sector. Naturally, it is expected that the Batu City Government will demand commitment and initiative to provide space for the participation of all parties, including farmer groups. The commitment and cooperation between sectors and between stakeholders need to be built. The government can support the needs and activities of extension workers, such as information technology extension (Fangohoi et al., 2018), improviement in the quality of extension programs, facilities and infrastructure for extension services to farmers, farming capital or other supporting facilities. The government can also take a role in controlling land conversion and land ownership.

\section{CONCLUSION AND SUGGESTION}

The performance of agricultural extension workers in Bumiaji District has been said to be good, including the development of farmer groups and joint farmer groups, work programs, extension media, extension methods and extension infrastructure. There is nly the performance of the approach method according to the farmers that is considered unsatisfactory.

The internal analysis of strengths and weaknesses of 2.03 and 1.98 , respectively, resulted in a score difference of 0.05 . Meanwhile the external conditions of opportunity and threats show the results of scores of 1.70 and 2.01 respectively, resulting in a score difference of -0.30 . The coordinates of the difference in scores place in quadrant IV on the SWOT diagram. The priority strategy for developing or improving extension services is Strength - Threat (ST). The strategy focuses on using force to overcome threats by conducting diversified programs.

The Batu Go Organic program will succeed if it is able to form farmers who independently apply organic farming. Farmers have the ability to help themselves to improve the welfare of their families.

The strategy prioritized by the BPP of Bumiaji District and the Agriculture Office of Batu City, namely:

1. Improving information flows about organic farming by providing extension methods.

2. Improving the ability of farmer groups by collaborating with stakeholders

3. Improving the effective and efficient counseling methods such as the use of internet facilities to increase farmer participation

4. Increasing the number of extension agents, both PPL and Assistant Staff

5. Improving the quality of HR extension agents

The results of this study provide the following recommendations:

1. Bumiaji district BPP should improve the performance of extension agents through improvements in facilities and infrastructure, information technology education, and improvement in the quality of extension programs.

2. The government should support and take a role in controlling land conversion and land ownership to ensure long-term land productivity.

\section{REFERENCES}

Aminah, S., Sumardjo, Lubis, D., \& Susanto, D. (2015). Strategi Peningkatan Keberdayaan Petani Kecil Menuju Ketahanan Pangan. Sosiohumaniora, 18(3), 253-261. Retrieved from

http://jurnal.unpad.ac.id/sosiohumaniora/article /download/8343/6617

Fadlina, I. M., Supriyono, B., \& Soeaidy, S. (2013). Perencanaan Pembangunan Pertanian Berkelanjutan (Kajian tentang Pengembangan Pertanian Organik di Kota Batu ) Sustainable Development of Agrocultural ( Studies on Organic Agricultural Development in Batu City). 
J-Pal, 4(1), 43-57. Retrieved from http://jpal.ub.ac.id/index.php/jpal/article/view/ $\underline{115 / 115}$

Fangohoi, L., Sugiyanto, S., Sukesi, K., \& Cahyono, E. D. (2018). Establish The Perception Of Agricultural Extension Workers Through Cyber Extension As The Media Information. Journal of Socioeconomics and Development, 1(1), 32-37. https://doi.org/10.31328/ised.v1i1.530

Hapsari, P. P., Hakim, A., \& Soeaidy, S. (2014). Pengaruh Pertumbuhan Usaha Kecil Menengah (UKM) terhadap Pertumbuhan Ekonomi Daerah (Studi di Pemerintah Kota Batu). Wacana-, 17(2), 88-96. Retrieved from http://wacana.ub.ac.id/index.php/wacana/articl e/view/308/259

Helms, M. M., \& Nixon, J. (2010). Exploring SWOT analysis - where are we now?: A review of academic research from the last decade. Journal of Strategy and Management, 3(3), 215-251. https://doi.org/10.1108/17554251011064837

Herlina. (2014). Interaksi Sosial Penyuluh Pertanian sebagai Upaya Peningkatan Usaha Tani
Masyarakat Petani di Kabupaten Batang. Journal of Educational Social Studies, 3(2), 3037. https://doi.org/10.15294/jess.v3i2.6651

Parmawati, R., Soemarno, Nugroho, I., \& Setiawan, B. (2012). The Effect of Asset Sustainable Livelihood to Development of Central Agriculture City. J. Appl. Environ. Biol. Sci, 2(3), 123-129.

https://doi.org/10.6084/m9.figshare.6265247

Sairi, A. (2015). Peran Petugas Penyuluh Pertanian Dalam Mengembangkan Budidaya Padi Di Desa Sumber Sari Kecamatan Loa Kulu Kabupaten Kutai Kartanegara. EJournal Ilmu Komunikasi, 3(2), 150-164. Retrieved from http://ejournal.ilkom.fisipunmul.ac.id/site/?p=1947\#

Sumbayak, P. H. (2013). Implementation Batu Local Govenment's Agriculture Policy Through Go Organic Programs In The Sustainable Agricultural Development. JURNAL ADMINISTRASI PUBLIK, 9(1). Retrieved from http://administrasipublik.studentjournal.ub.ac.id index.php/jap/article/view/291 